\title{
The Level of Competition Among the Deposit Money Banks (DMBs) in Nigeria
}

\author{
Bosede Olanike Awoyemi ${ }^{1,2}$, Josephine Onyinyechi Ihesiaba ${ }^{1}$ \\ ${ }^{1}$ Department of Economics, Afe Babalola University of Ado-Ekiti, Ado-Ekiti, Nigeria \\ ${ }^{2}$ Macroeconomics and Governance Division, United Nations Economic Commission for Africa (UNECA), Addis Ababa, Ethiopia
}

Email address:

nikeawoyemi@abuad.edu.ng (B. O. Awoyemi)

\section{To cite this article:}

Bosede Olanike Awoyemi, Josephine Onyinyechi Ihesiaba. The Level of Competition Among the Deposit Money Banks (DMBs) in Nigeria. International Journal of Business and Economics Research. Vol. 9, No. 4, 2020, pp. 176-182. doi: 10.11648/j.ijber.20200904.13

Received: April 14, 2020; Accepted: May 3, 2020; Published: June 17, 2020

\begin{abstract}
The level of competition in view of the financial performance of Deposit Money Banks (DMBs) between the periods of 2009 to 2018 was investigated. To measure competition, a four-firm Concentration ratio (CR4) and HerfindalHirschman Index (HHI) were used. To denote the percentage of market share that the individual bank has relative to the market size, the HHI and CR4 were computed from the individual bank's return on assets relative to the total assets of all the Deposit Money Banks in Nigeria. Simple arithmetic from excel workbook was done to estimate the competition indices (HHI and CR4). Data were obtained from the annual financial statement of the selected 15 deposit money banks in Nigeria. Descriptive statistics were used to show the trends of the top four (4) Concentration ratio (CR4) and Herfindal-Hirschman Index (HHI). It was also used to identify the characteristics of the Herfindal Hirschman Index (HHI) and Concentration Ratio CR of the Deposit Money Banks (DMBs). The descriptive statistics provide the summary statistics such as average value (mean), minimum and maximum values, median and standard deviation. The results indicated a high level of competition among the deposit money banks, and the banking industry was found to be highly competitive between the period of year 2009 and 2018.
\end{abstract}

Keywords: Competition, Herfindal-Hirschman Index (HHI), Market, Concentration Ratio (CR), Nigeria, Return on Asset (ROA), Banking Industry, Performance, Banks, Market Share

\section{Introduction}

The standard industrial organization literature emphasizes that higher level of competition is better. From a static point of view, competition increases welfare because competition reduces prices and increases the quantity and quality supplied in the market. Also, from a dynamic viewpoint, it can be said that competition increases the standard of living, if it increases the incentives for firms to innovate, although it is highly debatable [1]. In contrast to this, both economists and policy makers are convinced that competition in the banking sector is different. The presence of market failures explains why the standard competition paradigm is not directly applicable to the banking sector. Relationships in financial markets are characterized by asymmetric information, the presence of network externalities and (implicit) switching costs [2]. These market frictions and entry barriers explain why the market mechanism in financial markets might not function as well as it functions in other markets.
The competition encourages the emergence of banking institutions in Nigeria over the years as well as the competition from other credit institutes. This competition derived from the liberalization disables domestic firms to have high profits interfering with the net interest as a difference between a lending and a deposit rate and in the other ways. Increased competition from the financial sector, liberalization push the banking industry to a monopolistic competition. Banks reacted to the new operating business environment by changing their approach, pursuing new delivery channels and varying their management structures. This stiff competition gradually has become a problem to the financial performance of banks, especially the 2005 bank consolidation exercise and the 2008 global financial crisis. While the 2005 consolidation exercise was propagated to improve the competitiveness of the banks in Nigeria in terms of their capital base and hence increase their financial performance, the 2008 global financial crisis severely eroded the financial performance of banks in Nigeria. A lot of the 
banks were taken over by the government, despite receiving bailout funds. This stiff competition between deposit money banks has continuously increased over the past 20 years in Nigeria due to the various reforms such as recapitalization, removal of credit controls and liberalization in the financial sector. These reforms are to increase competition among banks and to eliminate liberalization barriers and increase efficiency of the banking system, thereby improving their financial performance. These reforms also aim to improve deposit creation which has brought about a higher degree of competition among deposit money banks. Competition and its effect on the performance of banks have been discussed extensively in developed countries, however, competition in the banking sector has received diminutive attention in the developing countries, especially in Nigeria. This situation is largely due to the difficulty in determining the appropriate measurement of competition, while many indicators have been put forward in the literature to capture bank performance. However, understand whether the banking sector is competitive or not, the empirical literature on the level of competition among deposit money banks in Nigeria must be derived. Hence, some common measures of competition from the literature are adopted so as to fill this gap and examine the dynamics of both competition and performance in the banking sector in Nigeria. On this note, the aim of this study is to examine the level of competition among the Deposit Money Banks (DMBs) in view of the performance of the DMBs in Nigeria. This study is divided into five sections, the first section covers the introduction and the objectives of the study, while section two and three contain the literature review and methodology. Section four covers the presentation and discussion of the findings, while section five concludes the study.

\section{Literature Review}

The Overview of the Nigerian Deposit Money Banks

The banking sector has sustained the Nigeria's economy in the past few years, by building the financial sector of the economy and by actively performing fundamental duties, which include the creation of money and deposit. The banking industry is made up of commercial banks now refer to as Deposit Money Banks usually and other Financial Institutions which includes mortgage banks and specialized/development banks. The activities in this industry are regulated by the Central Bank of Nigeria, the apex bank in Nigeria and it started operation in 1959. There was a national reform in the banking sector and this occasioned the recapitalization of commercial banks from 2- 25 billion Naira in 2004. Asides the capitalization reform of the Central Bank of Nigeria, there is also an introduction of banking automation and cashless policy, which enhances banking returns and addresses currency management. Under this reform, deposits from public sectors and government agencies tend to be retrieved by the commercial banks in order to enhance their level of liquidity.

There has been an argument of whether banks play a vital role in the development of the country among scholars. Few studies have contributed in this regard $[3,4,5]$. These studies provided evidence that supported the view that the deposit money activities play a major role in spurring economic growth in Nigeria. The banking system plays the most important role of financial intermediation through the mobilization and transfer of financial resources. Banks in performing their explicit role in the economy facilitate financial settlement through the payment system, influence money market rates and provide a means for international payment. The banking sector intermediate between the demand and supply of loanable funds as they mobilize funds and bridge the gap between the surplus and deficit units of the economy. By so doing, the deposit money banks, mobilizes savings for investment purposes [6]. To mobilize savings, the banks receive deposits and from the deposits create money in circulation. Schumpeter [7] argues that financial institutions are necessary for economic development. The deposit money banks in Nigeria are financial institutions licensed and regulated by the central bank to facilitate movement of funds to different economic units and ensure adequate flow of funds in the economy, while performing other financial services. Deposit money banks otherwise known as commercial banks are a key factor in the financial sector in Nigeria. The 2004 bank consolidation reform through mergers and acquisitions, lead to a decrease in the number of banks from 89 to 25 in 2005. The number was later reduced in 2007 to 24 and in 2017, only 16 deposit money banks were listed on the Nigerian stock exchange [5]. This persistent reduction in the number of banks is presumed to have an influence on the competitive behavior of the banks in Nigeria.

Theoretical and Empirical Literature

A Structure-conduct-performance

The SCP approach links the structure of a market/industry to the conduct of firms in that market and thereby to performance. In particular, the SCP paradigm posits that there is an increasing relationship between the level of market concentration and market power. Pure competition is the only market structure in which the firms competing lack any degree of market power. Pure monopolists, in contrast, and firms operating under conditions of oligopoly or monopolistic competition appreciate that their own output decisions can have a non-trivial influence on price. The SCP paradigm is based on the assumption that the latter group will in fact exercise their market power. The SCP states that the performance of banks essentially depends upon the structure of the industry such as the number of banks and the market shares of banks (these are measures of industry concentration). The level of concentration of the banks within the banking industry determines the level of competitive behavior of the banks. In other words, the higher the concentration ratio, the lower will be the level of competition among banks, reflecting a negative association between concentration and competition. Therefore, the SCP hypothesis emphasizes the importance of increased concentration with a view to reducing competitive behavior 
of banks [8].

Many studies have provided an argument for and against competition as a determinant of bank performance, some studies express their views in favor of competition. Enendu et al, [9] revealed that one benefit of the 2004/2005 bank consolidation exercise and other complementary reforms in the banking industry in Nigeria was competition, which raised efficiency and profitability. Berger et al, [10] indicated that the intention of the government to limit competition through the entry regulation of foreign bank and state proprietorship of banks could negatively affect the economic efficiency. Calem and Carlino [11] point out that higher concentration industry is less competent and equitable, thereby more vulnerable to crisis. However, [12] pointed out that increased competition in the banking industry provides less incentive for banks in intensive monitoring and screening of loans, which has bad effects on the financial stability. Therefore, based on the above view, it can be reasoned that the nature of the link between competition and bank performance is rather ambiguous. Various measures of market structure have been devised and are widely used in empirical work. For instance, banks 'holdings of assets and deposits are usually used to construct measures of concentration in the banking sector, expressed as the share of the largest four or five institutions. Decreases in concentration ratios are generally interpreted as indications of increased competition. A decline in the ratio might reflect a decline in the market share of the largest firms, owing perhaps to new entrants capturing some customers, thus increasing the level of competition.

\section{Direct Measures of Bank Competition}

Concentration Ratio: A concentration ratio (CR) is the percentage of industry total output that a certain number of bigger firms have. It is the ratio of market shares of selected number of firms to the aggregate market size. Concentration ratio is used to measure the degree to which a market is concentrated. The concentration ratio for some $\mathrm{n}$ largest firms in an industry is calculated simply by adding up the market shares of these $\mathrm{n}$ firms. CR4, which measures the market share of four top firms in the industry is the commonly used concentration ratio, it is calculated as $\mathrm{CR} 4=\mathrm{S}_{1}+\mathrm{S}_{2}+\mathrm{S}_{3}+$ $\mathrm{S}_{4}$. As explained by [13], a $\mathrm{CR}_{4}$ with a numerical value of $0 \%$ denotes a perfect competition. Value $>0 \%<40 \%$ implies a market structure with monopolistic competition, while value $\geq 40 \% \leq 60 \%$ indicates oligopoly market. A value greater than or equal to $90 \%$ corresponds to a monopoly.

Herfindahl-Hirschman Index (HHI): This is a square of the market share of each firm competing in a market, and then summing the resulting numbers, and can range from zero to 10,000 . This is represented as $\mathrm{HHI}=\mathrm{S}_{1}{ }^{2}+\mathrm{S}_{2}{ }^{2}+\mathrm{S}_{3}{ }^{2}+\mathrm{S}_{4}{ }^{2}+$ $\mathrm{S}_{5}{ }^{2}+\ldots+\mathrm{S}_{\mathrm{n}}{ }^{2}$, where $\mathrm{S}_{\mathrm{i}}$ is the market share of the ith firm. HHI has advantages over the $\mathrm{N}$-firm concentration ratio. The HHI presents the distribution of the market shares of the top four firms and the structure of the market of the top four firms. Also, HHI gives greater weight to the market shares of the larger firms. This identifies the larger firms' share relative to the small firms in competitive interactions. The DOJ [14] and the Federal Trade Commission horizontal merger guidelines present the spectrum of market concentration as measured by the HHI into three groupings that can be broadly characterized as low concentration (HHI below 1000), moderately concentrated (HHI between 1000 and 1800), and highly concentrated (HHI above 1800).

Empirical Reviews

A number of papers have investigated the competitive condition in banking systems. Enendu et al, [9] used HHI with respect to assets and deposits to measure competition in the banking sector. It was found that HHI increased after the bank consolidation exercise and the industry remained largely competitive, as concentration declined slightly. For the study, one benefit of the 2004/2005 bank consolidation exercise and other complementary reforms delivered to the banking industry in Nigeria was a slightly less concentrated market, which raised efficiency and profitability. As indicated by [15] the degree of competition is one of the three interrelated and dominant determinants of bank performance aside financial reform and the risk-taking attitude of banks. Casu and Girardone [16] investigated the association between competition and bank performance measured by the efficiency in banking markets. The results suggest unidirectional causality between efficiency and competition, the causality running from competition to efficiency was positive but weakly significant. Mugume [17] analyzed the competitive behavior of Uganda's banks and found that market power and concentration as measured by HHI and market share positively affect bank performance as competition increases banks' profitability. Although the degree of competition in the Ugandan banking sector tends to be weaker as a negative relationship was obtained between competition and the market structure indicating that a few large banks can restrict competition. Ajisafe and Akinlo [18] observed the link between competition and efficiency of deposit money banks in Nigeria and the findings show a direct and strong correlation between the efficiency of deposit money banks and competition. Bajomo and Akinlo, [19] confirms that the level of competitiveness of the Nigerian banking is found to be strong when competitiveness is measured in terms of each operator's market power, which is captured by concentration ratio.

Moreover, Naceur and Omran [20] examined the influence of bank regulation, concentration, financial and institutional development on commercial bank margins and profitability across a broad selection of Middle East and North Africa (MENA) countries. The empirical results suggest that bank capital/asset and credit risk significantly and positively influence banks' net interest margin, profitability and cost efficiency. However, [21] find that the augmented use of securitization action in the banking sector prior to the 20072009 crisis increased the effect of competition on bank risk, meaning that higher level of competition and more of securitization is associated with high realized risks in the period of the crisis. The empirical findings suggest that banking competition has both positive and negative effects, 
thus, there is inconclusive evidence as it is hard to establish which one dominates.

Furthermore, [22] observed the impact of interest rate spread on the performance of the Nigerian banking industry and obtained that there is high interest rate spread in the long run, which negatively influence the performance of banks in Nigeria. As opined by the Chand [23], this negative effect is as a result of several reasons which include, lack of adequate competition among banks, high fixed and operating costs, and high transportation and communication costs among others. Uddin and Suzuki [24] assessed the relationship between bank performance and competition by using banking sector data (1983-201 and individual bank data (2001-2011) from Bangladesh. Return on assets was used to measure bank performance, HHI, concentration ratio and to capture the level of competition. Regression analysis was done to analyze the impact of competition on the bank performance measures. The findings revealed an increase in bank performance and an increase in the level of competition in the banking sector. A negative association was found to exist between competition and bank performance from the regression results.

\section{Methodology}

This study spans from 2009-2018 periods, the data were sourced from the annual reports and statement of accounts of 15 commercial banks in Nigeria. The banks were selected based on the accessibility to their statement of accounts and annual report, which covers the period of study. These 15 banks are Zenith Bank PLC, Guaranty trust bank PLC, Union bank of Nigeria (UBN), First Bank of Nigeria (FBN), and United Bank for Africa (UBA), Access Bank, Diamond Bank, Eco Bank Nigeria PLC, Fidelity Bank PLC, First city monument bank, Skye bank, Stanbic IBTC bank, Sterling bank PLC, WEMA bank, Unity bank PLC. From the
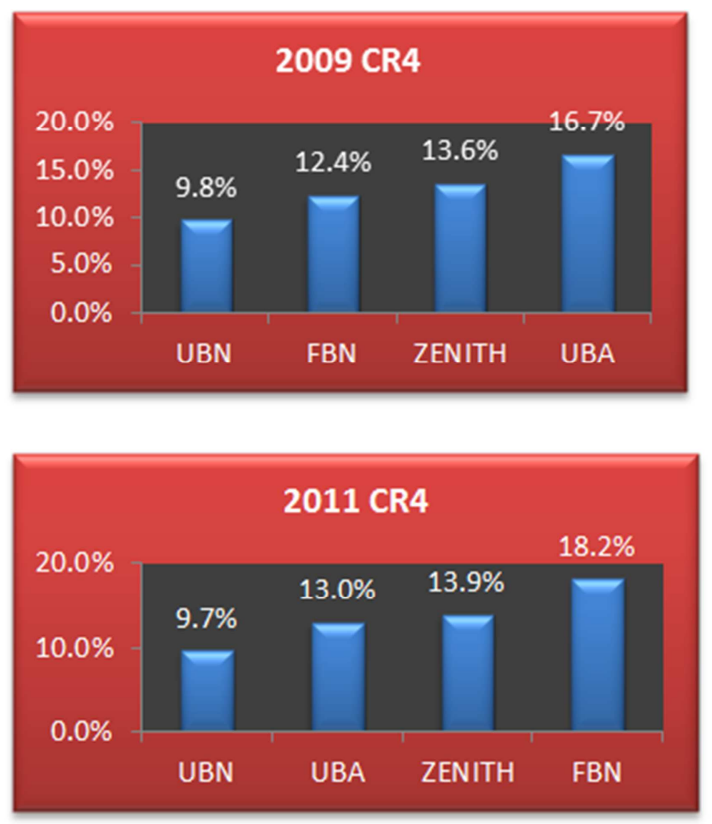

literature, there were various measures of competition, but the commonly used methods are the Herfindal Hirschman Index (HHI) and Concentration Ratio CR. These methods were applied in this study to measure competition among DMBs in Nigeria. In this study we made use of four-bank concentration ratio $\left(\mathrm{CR}_{4}\right)$ which denotes the percentage of market share that the top four banks have relative to the market size. The HHI and $\left(\mathrm{CR}_{4}\right)$ equation was expressed as follows;

$$
\begin{gathered}
H H I=\sum_{i=1}^{n} M S_{i}^{2} \\
i=1,2, \ldots ., N \\
C R_{4}=M S_{1}+M S_{2}+M S_{3}+M S_{4}
\end{gathered}
$$

Where

$\mathrm{MS}=$ Market share of individual bank. This is the individual asset of a bank relative to the total assets of all DMBs in Nigeria. CR4 is the concentration ratio of the top 4 banks in the banking market. To estimate the individual bank market share, return on assets was employed. Return on assets is calculated as net income (or pre-tax profit)/total assets. Profit before tax is used because using net income after tax values may show drifts due to changes in the tax rate [25]. The data collected were analyzed using simple arithmetic and descriptive statistics computed from STATA statistical software. These statistics provide summary statistics such as average value (mean), median and standard deviation.

\section{Results and Discussion}

Descriptive Statistics
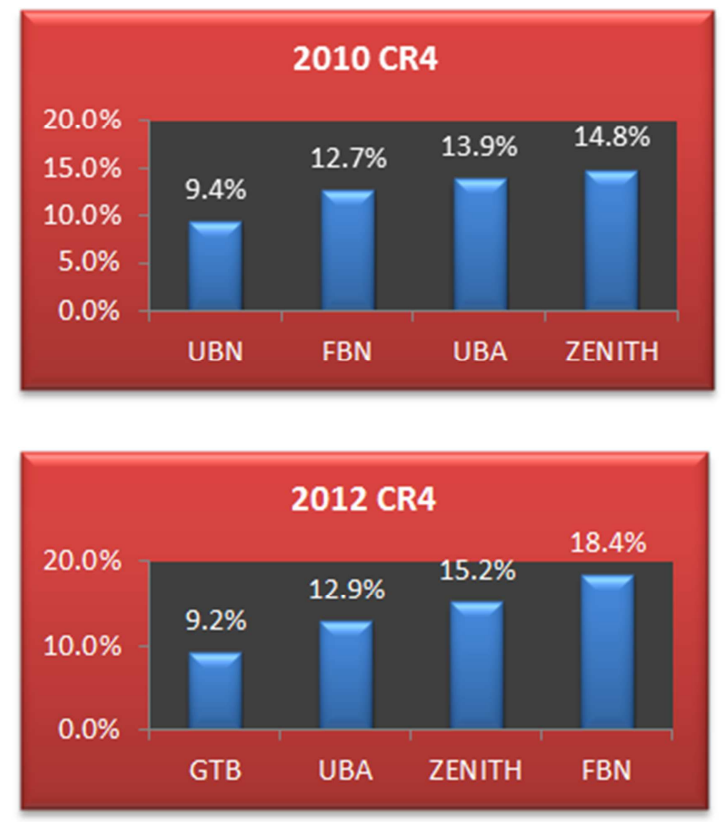

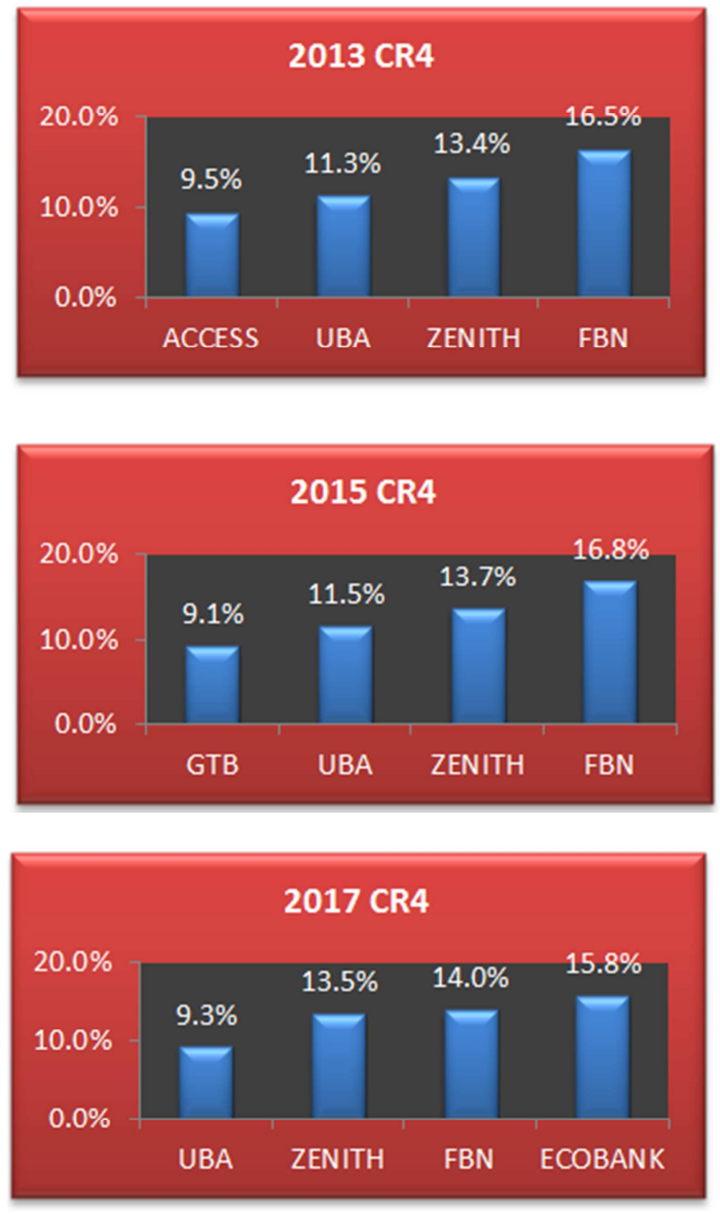
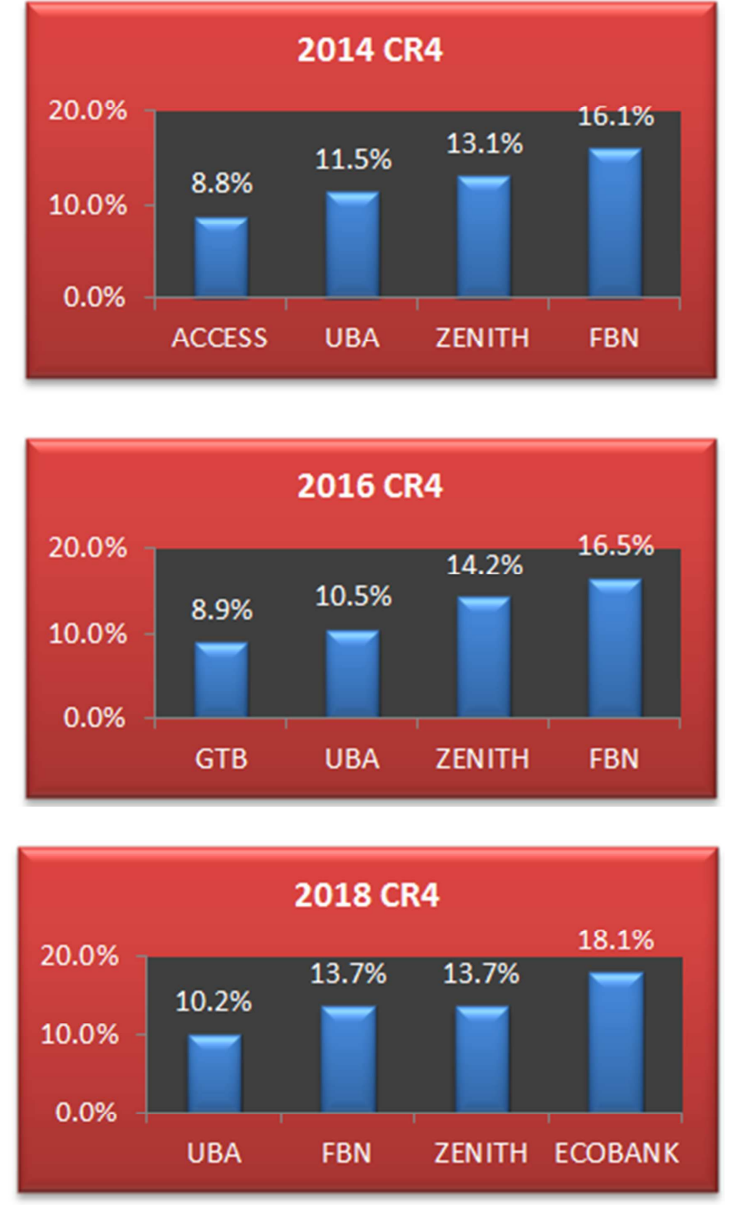

Figure 1. Concentration Ratio for 4 Banks between 2009 and 2018.

To ascertain the level of competition, this section shows the trends of the top four (4) Concentration ratio (CR4) and Herfindal-Hirschman Index (HHI) (indicators of competition) for the selected banks during the period of the study. It also shows the numbers of observations, mean, median, maximum, minimum and standard deviations of all the variables considered in this study. Again, the market shares of the top four (4) banks between 2009 and 2018 that is then presented in the Figure 1, explicitly, the figure visibly shows that the $52.42 \%$ market concentration in 2009 is maintained by UBN, First Bank of Nigeria (FBN), Zenith Bank and UBA. During the years, the CR4 declined and climbed up with some modifications in the composition of the group. However, it is important to note that First Bank of Nigeria (FBN) tops the list of the top4 banks for five (5) consecutive years and in recent years Ecobank has taken over. This may be as a result of the bank's (Ecobank) 'one bank concept' which necessitated the full presence of the Ecobank Transnational Incorporated (ETI), the parent company of the Ecobank Group on the Nigerian Stock Exchange (NSE).

Descriptive Statistics for the Measure of Competition and Performance Indicators

Descriptive results of return on asset (ROA), the top four (4) concentration ratio (CR4) and HerfindalHirschman Index (HHI) showing the number of observations, mean, standard deviation, minimum, and maximum are presented in Table 1. From the table, the mean value of the return on asset (ROA) is $0.90 \%$. This suggests that on the average, all the sampled bank's ratio of net income to total asset is $0.90 \%$. The maximum and minimum values of $-24.24 \%$ and $10.64 \%$ indicate that the banks recorded negative (losses) and positive (profits) returns during the years. In addition, the standard deviation of 10.64 suggests that the performance of the banks varies considerably. The average value of the top 4 banks is $52.36 \%$, implying that the four (4) banks on the average control about $52.36 \%$ of the market share during the period of the study. Similarly, the average value of the overall concentration ratio is $6.67 \%$ with the minimum and maximum values of $1.23 \%$ and $18.44 \%$ respectively. According to the extant literatures concentration ratio that is below $50 \%$ indicates perfectly competitive or low concentration while the concentration ratio between $50 \%$ and $80 \%$ and above $8 \%$ indicate medium and high concentration (oligopoly). Nevertheless, going by average, minimum and maximum values, the market is perfectly competitive. Focusing on the HHI values, the average is 971.68 which is less than 1000 also indicating a competitive market. Also, the minimum value is 917.79 and the maximum value is 1049.80 . 
Table 1. Descriptive Statistics.

\begin{tabular}{lllll}
\hline VARIABLES & Mean & Std. & Min & Max \\
\hline ROA & 0.90 & 3.48 & -24.24 & 10.64 \\
CR4 & 52.36 & 2.24 & 49.42 & 55.74 \\
CR & 6.67 & 4.52 & 1.23 & 18.44 \\
HHI & 971.68 & 46.94 & 917.79 & 1049.80 \\
\hline
\end{tabular}

Source: Author's computation

The measures of the level of competition among the DMBs in Nigeria

Concentration Ratio

The market shares of the top 4 banks between 2009 and 2018 is presented in Table 2 . The table clearly shows that the CR4 is about $52.42 \%$ in 2009 indicating that only four banks representing $26.7 \%$ of the entire banks control $52.42 \%$ of the market share of Total asset during the years The CR4 rose to $55.72 \%$ in 2018 though; it dropped to $49.42 \%$ in 2014 . This simply indicates that just $26.7 \%$ of the selected banks control more than half of the market share at the end of 2018 .

Table 2. Concentration Ratio for 4 Banks between 2009 and 2018.

\begin{tabular}{ll}
\hline Year & CR4 \\
\hline 2009 & 52.42 \\
2010 & 50.80 \\
2011 & 54.91 \\
2012 & 55.74 \\
2013 & 50.67 \\
2014 & 49.42 \\
2015 & 51.15 \\
2016 & 50.10 \\
2017 & 52.62 \\
2018 & 55.72 \\
\hline
\end{tabular}

Notes: Table 2 presents Concentration Ratio for 4 Banks considered between 2009 and 2018

\section{Herfindal-Hirschman Index}

The result of the Herfindal-Hirschman Index (HHI) computed from the concentration ratio for all the banks between 2009 and 2018 is presented in Table 3. HHI takes values between 0 and 10,000 and [14] established that HHI that is less than 1,000 indicates low concentration and high competition. Similarly, HHI between 1,000 and 1,800 indicate medium concentration or moderately concentrated marketplace and HHI that is more than 1,800 is a highly concentrated marketplace. However, given the result in the Table 3, the banks do not follow the oligopolistic structure. Alternatively, the results generally indicate that the marketplace is highly competitive between the years 2009 and 2018.

Table 3. Herfindal-Hirschman Index (HHI) for all the Banks between 2009 and 2018

\begin{tabular}{ll}
\hline Year & HHI \\
\hline 2009 & 940.18 \\
2010 & 939.33 \\
2011 & 1025.70 \\
\hline
\end{tabular}

\begin{tabular}{ll}
\hline Year & HHI \\
\hline 2012 & 1041.76 \\
2013 & 941.63 \\
2014 & 917.79 \\
2015 & 943.67 \\
2016 & 936.38 \\
2017 & 980.54 \\
2018 & 1049.80 \\
\hline
\end{tabular}

Notes: Table 3 presents HHI for all the Banks considered between 2009 and 2018.

\section{Conclusion and Recommendation}

The study examined the level of competition among the deposit money banks in Nigeria using the Herfindal Hirschman Index (HHI) and Concentration Ratio to measure competition indices for the DMBs in Nigeria. The CR4 (Concentration Ratio) for the banking sector, which was derived shown that just $26.7 \%$ of the selected banks control more than half of the market share at the end of 2018. The result of the Herfindal-Hirschman Index (HHI) computed for all the banks between 2009 and 2018 was more than 2,500 which indicated a highly concentrated market. By implication, the level of competition among the deposit money bank was high and the market was highly competitive within the time frame of the 2009-2018 periods. In view of the results from the HHI and CR4, this study concluded that there is a low level of concentration, which implies a high level of competition. Therefore, concentration in the Nigerian banking sector, especially among the Deposit Money Banks is said to be low and this makes the industry to have high level of competition. Following the findings of [9], this has potential to raise efficiency and profitability, as well as to reduce banks vulnerable to crisis [11], thereby increasing the overall performance of the banks. However, as competition has positive effect on the bank performance, it also has its negative effect as opined by [12], high level of competition may affect the banks' financial stability as banks are less motivated to be thorough in their duties in monitoring and screening loans given to customers in order to attract more customers. On this note, the study suggests that the bank regulator, which is the central bank should promote policies that will ensure healthy competition among deposit money banks so as to reduce the negative effect of competition on bank financial performance.

\section{Acknowledgements}

The authors acknowledge the support of the United Nations Economic Commission for Africa (UNECA) in providing facilities during the write of this paper. The views expressed in this paper are those of the authors and do not represent that of the United Nations. The authors also acknowledge the support of John Awoyemi for proofreading this work and the staff of Economics Department, Afe Babalola University Ado-Ekiti, who provided comments to improve this work. 


\section{References}

[1] Aghion, P., Carlin, W., \& Schaffer, M. E. (2002). Competition, innovation and growth in transition: Exploring the interactions between policies.

[2] Allen, F., Carletti, E., \& Gu, X. (2008). The roles of banks in financial systems. Prepared for the Oxford Handbook of Banking edited by Allen Berger, Phil Molyneux, and John Wilson.

[3] Adegboye, F. B., Olowe, O., \& Uwuigbe, O. R. (2013). Returns on investment of deposit money banks (DMBs) in Nigeria. Journal of Applied Finance \& Banking, 3 (3), 195206.

[4] Olokoyo, F. O., Taiwo, J. N., \& Akinjare, V. A. (2016). The Impact of Banks' Activities on Economic Development in Nigeria. International Business Management, 10 (22), 53415351 .

[5] Abdulateef, Y., Ekundayo, O., \& Mizita, O. Q. (2019). Determinants of Survival of Listed Deposit Money Banks in Nigeria. European Journal of Accounting, Auditing and Finance Research. 7 (3); 20-40.

[6] Mordi, C. N. (2010). The link between the financial (banking) sector and the real sector of the Nigerian economy.

[7] Schumpeter, J. (1934). The theory of economic development Harvard University Press. Cambridge, MA.

[8] Bikker, J. A. and Haaf, K. (2002) 'Measures of competition and concentration in the banking industry: a review of the literature', Economic and Financial Modelling, (9).53-98.

[9] Enendu, C. I.; Abba, M. A.; Fagge, A. I.; Nakorji, M.; Kure, E. U.; Bewaji, P. N.; Nwosu, C. P.; Ben-Obi, O. A.; Adigun, M. A.; Elisha, J. D.; Okoro, A. E and Ukeje N. H (2013). Bank Intermediation in Nigeria: Growth, Competition and Performance of the Banking Industry, 1990 - 2010. Occasional Paper no 48, Central Bank of Nigeria. Abuja, Nigeria.

[10] Berger, A. N., Demirguc-Kunt, A., Levine, R. and Haubrich, J. G. (2004) 'Bank concentration and competition: an evolution in the making', Journal of Money, Credit and Banking, 36 (3); 433-451.

[11] Calem, P. S. and Carlino, G. A. (1991) 'The concentration/conduct relationship in bank deposit markets', The Review of Economics and Statistics. 73 (2); 268-276.

[12] Casu, B., Ferrari, A. and Zhao, T. (2010) 'Financial reforms, competition, and risk in banking markets', in Fiordelisi, F., Molyneux, P. and Previati, D. (Eds): New Issues in Financial and Credit Markets, Palgrave Macmillan, Basingstoke. 111120.
[13] Gwin, C. R. (2001). A Guide for Industry Study and the Analysis of Firms and Competitive Strategy. Babson College Horn Library at http://www.babson.edu/library/. Accessed online, (2015).

[14] The DOJ and the Federal Trade Commission Horizontal Merger Guidelines. Available at http://www.usdoj.gov/atr or http://www.ftc.gov/

[15] Athanasoglou, P. P., Brissimis, S. N., \& Delis, M. D. (2008). Bank-specific, industry-specific and macroeconomic determinants of bank profitability. Journal of international financial Markets, Institutions and Money, 18 (2), 121-136.

[16] Casu, B., Girardone, C., \& Molyneux, P. (2012). Is there a conflict between competition and financial stability? Research Handbook on International Banking and Governance, part, 1.

[17] Mugume, A. (2010). Competition and Performance in Uganda's Banking System. AERC Research paper 203. Nairobi. Retrieved online at https://www.africaportal.org/publications/competition-andperformance-in-ugandas-banking-system/.

[18] Ajisafe, R. A., \& Akinlo, A. E. (2014). Competition and Efficiency of Commercial Banks: Empirical Evidence from Nigeria. American Journal of Economics, 4 (1), 18-22.

[19] Bajomo, O. A. Akinlo, A. E. (2018). Consolidation, Reforms and Profitability of Deposit Money Banks: Evidence from Nigeria. Archives of Business Research, 6 (8); 376-395.

[20] Naceur, S. B., \& Omran, M. (2011). The effects of bank regulations, competition, and financial reforms on banks' performance. Emerging Markets Review, 12 (1), 1-20.

[21] Altunbas, Y., Van Leuvensteijn, M., \& Marqués-Ibáñez, D. (2014). Competition and bank risk: the effect of securitization and bank capital (No. 1678).

[22] Obidike, P. C., Ejeh, G. C., \& Ugwuegbe, S. U. (2015). The impact of interest rate spread on the performance of Nigerian Banking Industry. Journal of economics and sustainable development, 6 (12), 131-139.

[23] Chand, S. (2003). An assessment of the proposal for a Pacific Economic and Political Community. Pacific Economic Bulletin, 18 (2), 117-124.

[24] Uddin, S. S., \& Suzuki, Y. (2014). The impact of competition on bank performance in Bangladesh: an empirical study. International Journal of Financial Services Management 2, 7 (1), 73-94.

[25] Zhou, J. (2009). The asset location puzzle: Taxes matter. Journal of Economic Dynamics and Control, 33 (4), 955-969. 